\title{
EKSISTENSI LEMBAGA BANTUAN HUKUM (LBH) CIREBON DALAM PENDAMPINGAN PERKARA PIDANA DI PENGADILAN NEGERI CIREBON*
}

\author{
Diding Rahmat \\ Fakultas Hukum Universitas Kuningan \\ Email:didingrahmat1@gmail.com
}

\begin{abstract}
Researchers conducted a study entitled The existence of the Legal Aid Institute $(\mathrm{LBH})$ Cirebon in handling Criminal case in Cirebon District Court. The research location is in Cirebon Legal Aid Institute (LBH) and Cirebon District Court, as for the formulation of research problem is how the arrangement of legal aid under Republic Act \# 16 of 2011 About Legal Aid? How the existence of the Cirebon Legal Aid Institute (LBH) in handling cases in the District Court of Cirebon? The purpose of this study is to investigate the regulation of the Legal Aid Legal Aid agencies pursuant to Law 16 of 2011, how the existence of the Cirebon Legal Aid Institute (LBH) in handling criminal cases in the District Court of Cirebon. This research could be useful in a practical and theoretical, in practice, could be used as a practical policy in handling cases by Legal Aid, especially LBH Cirebon and theoretically could be a treasury of knowledge of criminal law legal aid especially in criminal cases. The method used by the researchers is the evaluative method of analysis, which is a method of collecting and presenting data obtained to analyze the actual situation and then do a rational analysis based on the reference of juridical through library research and field research.
\end{abstract}

Abstrak
Peneliti melakukan penelitian yang berjudul Eksistensi Lembaga Bantuan Hukum (LBH)
Cirebon dalam peenanganan Perkara Pidana di Pengadilan Negeri Cirebon. Lokasi
penelitian dilakukan di Lembaga Bantuan Hukum (LBH) Cirebon dan Pengadilan Negeri
Cirebon, adapun rumusan penelitian yang dirumuskan menjadi tititk permasalahan
adalah bagaimana pengaturan lembaga bantuan hukum menurut Undang-undang RI
No.16 Tahun 2011 Tentang Bantuan Hukum? Bagaiman Eksistensi Lembaga Bantuan
Hukum (LBH) Cirebon dalam penanganan perkara di Pengadilan Negeri Cirebon?
Adapun tujuan penelitian ini adalah untuk mengetahui regulasi tentang Bantuan
Hukum terhadap lembaga Bantuan Hukum berdasarkan Undang-undang No.16 Tahun
2011, bagaimana Eksistensi Lembaga Bantuan Hukum (LBH) Cirebon dalam penanganan
perkara Pidana di Pengadilan Negeri Cirebon. Penelitian ini dapat berguna secara
praktis dan teoritis, secara praktis dapat digunakan sebagai acuan kebijakan praktis
dalam penanganan perkara oleh Lembaga Bantuan Hukum khususnya LBH Cirebon dan
secara teoritis dapat menjadi khasanah ilmu pengetahuan hukum pidana khusunya
menyengkut bantuan hukum perkara pidana. Metode penelitian yang digunakan oleh
peneliti adalah metode evaluative analisis, yaitu suatu metode mengumpulkan dan

- Artikel ini hasil penelitian hibah Penelitian Dosen Universitas Kuningan No.2.037/SPK/LPPM-UNIKU?/KNG/2015, tanggal 27 Mei 2015. 
menyajikan data yang diperoleh untuk menganalisis keadaan yang sebenarnya dan selanjutnya dilakukan analisis rasional berdasarkan acuan yuridis melalui penelitian kepustakaan dan penelitian lapangan.

Kata kunci : Hukum, Lembaga Bantuan Hukum, Perkara Pidana

\section{A. Pendahuluan}

Indonesia adalah negara hukum (Rechtsstaat) hal tersebut tertuang dalam Undang Undang Dasar 1945 yaitu pasal 1 ayat (3) menyatakan bahwa "Negara Indonesia adalah negara hukum ". Sebagai negara hukum maka negara harus memberikan perlindungan hukum menyangkut hak asasi warga negara dan menjamin persamaan di depan hukum. Hukum sebagai kaedah sosial hadir sebagai jawaban dari kaedah kaedah yang sebelumnya ada yaitu kaedah kesopanan, kaedah kesusilaan dan kaedah keagamaan tentu kehadiran kaedah hukum memberikan solusi dan penataan hubungan masyarakat sebagai mahluk sosial agar terciptanya keadilan, kebahagiaan, keadamaian dan ketentraman sebagaimana tertuang dalam tujuan hukum baik teori etis, utilitis maupun teori campuran. ${ }^{1}$

Persamaan di depan hukum dan pemerintahan sebagaimana pasal 27 ayat(1) Undang Undang Dasar 1945 mengisyaratkan bahwa semua orang sama di depan hukum tidak terkecuali (Equality Before the Law). Hal tersebut menggariskan bahwa warga negara Indonesia baik kaya maupun miskin, pejabat atau rakyat biasa, perempuan ataupun laki laki serta dewasa ataupun anak anak memiliki persamaan dalam hukum tentu ini menyangkut tindak pidana. Asumsi bahwa hukum tajam kebawah dan tumpul keatas harus di singkirkan dalam proses pelaksanaan asas hukum setara terutama dalam penanganan perkara tindak pidana.

\footnotetext{
${ }^{1}$ Sudikno Mertokusumo, Mengenal Hukum Suatu Pengantar, Liberty, Yogyakarta,2007,hlm.77.
} 
Hukum pidana dalam pengertianya menurut Mr.W.F.C Van Hattum adalah suatu keseluruhan dari asas asas dan peraturan peraturan yang diikuti oleh negara atau suatu masyarakat hukum umum lainya, dimana mereka itu sebagai pemelihara dari ketertiban hukum umum telah melarang dilakukanya tindakan tindakan yang bersifat melanggar hukum dan telah mengaitkan pelanggaran terhadap peraturanperaturanya dengan suatu penderitaan yang bersifat khusus berupa hukuman. $^{2}$

Maka dapat disimpulkan bahwa hukum pidana adalah ketentuan aturan yang berisikan pelanggaran dan kejahatan kemudian orang yang melakukan kejahatan dan pelanggaran serta sanksi terhadap orang yang melakukan pelanggaran dan kejahatan. Sehingga dalam hukum pidana ada tiga unsur yaitu: Aturan, Orang dan Sanksi. Kemudian tindak pidana menurut Muljatno adalah perbuatan yang dilarang oleh suatu peraturan hukum dan larangan mana disertai ancaman (sanksi) yang berupa pidana tertentu, bagi barang siapa melanggar larangan tersebut. ${ }^{3}$

Dengan demikian bahwa perkara pidana adalah ketika orang melakukan tindak pidana baik pelanggaran maupun kejahatan yang diancam dengan hukuman sesuai dengan aturan yang ada, sebagaimana dikemukakan diatas bahwa semua orang sama didepan hukum memilki dimensi yang luas ketika dipertnayakan yaitu apakah betul? Bagimana nasib orang miskin yang sedang mengalami musibah terutama perkara pidana? Dan bagaimana proses pengawasan agar pelaksanaan proses

2 PAF. Lamintang, Dasar Dasar Hukum Pidana Indonesia, Citra Aditya Bakti, Bandung,1983, hlm.2

3 Adami Chazawi, Pelajaran Hukum Pidana 1, Raja Grafindo Persada,Jakarta,2002,hlm.71 
pemidaanya tidak melanggar aturan dan sesuai dengan prinsip-prinsip Hak Asasi Manusia, pertanyaan demikan menjadi penting dalam memberikan rasa keadilan bagi masyarakat khusunya masyarakat tidak mampu dan diancam lebih dari 5 tahun penjara.

Tujuan hukum pidana adalah untuk melindungi masyarakat dari kesewenang wenangan penguasa, untuk menghilangkan orang jahat dan memberikan rasa aman dan terib dimasyarakat, tujuan tersebut akan berjalan apabila adanya kesatuan antara aturan dan penegakan hukum oleh aparat serta kesadaran masyarakat kemudian peranan advokat dan lembaga bantuan hukum untuk bersama sama mewujudkan tujuan hukum pidana diatas.

Dalam teorisasinya hukum pidana menurut Prof Van Hammel terbagi dua yaitu pidana materil dan pidana formil. Pidana materil menunjukan asas-asas dan peraturan-peraturan yang mengaitkan pelanggaran hukum itu dengan hukuman, sedangkan hukum pidana formil menunjukan bentuk-bentuk dan jangka-jangka waktu yang mengikat pemberlakuan hukum pidana materil. ${ }^{4}$

Dengan demikian bahwa antara pidana materil dan pidana formil merupakan satu kesatuan yang utuh yang tidak bisa dipisahkan dalam pelaksanaan penegakan hukum pidana agar sesuai dengan tujuan dan fungsi, lebih sederhanya adalah kesatuan anatara KUHP (Kitab Undangundang Hukum Pidana) dan KUHAP (Kitab Undang-undang Hukum Acara Pidana) sebagai pelaksananya dalam menjalankan pidana materil.

Penegakan hukum pidana ujungnya berada di pengadilan oleh karena itu proses persidangan dipengadilan sangat penting karena menentukan

4 PAF. Lamintang, Dasar Dasar Hukum Pidana Indonesia, Citra Aditya Bakti, Bandung,1983, hlm.10 
baik buruknya penegakan hukum melalui putusan pengadilan tersebut sesuakah dengan asas asas penegakan hukum yaitu kemanfaatan, keadilan dan kepastian, hak terdakwa dalam pendampingan perkara oleh advokat, penasihat hukum atau pemberi bantuan hukum sangat penting untuk mencegah adanya penyimpangan proses persidangan yang dapat dilakukan oleh jaksa maupun hakim dalam putusanya. Dalam proses penegakan hukum di Indonesia salah satu unsurnya adalah aparat hukum yang banyak dikenal dengan istilah catur wangsa (polisi, hakim, jaksa dan advokat) namun demikian prose pengadilan sebagai ujung keadilan menjadi amatlah menuntukan nasib terdakwa, oleh karena peran pendampingan dari pemberi bantuan hukum atau advokat menjadi suatu keharusan.

Sejarah bantuan hukum sudah ada sejak lama baik di internasional maupun di Indonesia hal tersebt membuktikan peranan bantuan hukum sangatlah penting sebagai bagian dari proses penegakan hukum. Bantuan hukum hadir akibat kesadaran masyarakat kita masih rendah tehadap pemahaman akan hak-hak hukum, menyangkut proses atau hal tekhnis lainya termasuk juga informasi mengenai kemampuan materi untuk menggunakan jasa bantuan hukum yang bisa diakses secara geratis bagi masyarakat yang tidak mampu. Masyarakat tidak mampu berhak mendapatkan jasa bantuan hukum dan pendampingan dalam perkara perkara hukum yang sedang dialaminya secara litigasi maupun non litigasi ini adalah bentuk tanggung jawab negara dalam rangka melindungi warganya dari perlindungan hukum sebagaimana amanat pasal 27 ayat (1) Undang-undang Dasar 1945 yang diturunkan kepada Undang -Undang No.16 Tahun 2011 Tentang Bantuan Hukum. 
Pemberian bantuan hukum dalam perkembanganya ada yang bersifat individu perorangan seperti advokat atau pengacara, kantor hukum dan juga lembaga bantuan hukum yang banyak dijumpai baik di tingkat nasional ataupun di daerah kota atau kabupaten kemudian ada juga lembaga bantuan hukum yang keberadaanya di kampus atau universitas. Lembaga Bantuan Hukum hadir untuk melindungi masyarakat kecil dari permasalahan hukum yang dihadapinya dengan cara melakukan pendampingan secara litigasi dan non litigasi ini bertujuan agar hak hak masarakat dapat diawasi dan dikontrol oleh lembaga bantuan hukum, konsep ini tertuang dalam anggaran dasar dan rumah tangga lembaga bantuan hukum yaitu :

1. Memberikan pelayanan hukum bagi rakyat miskin.

2. Meningkatkan dan mengembangkan kesadaran hukum masyarakat, terutama mengenai hak-haknya sebagai subyek hukum.

3. Mengusahakan perubahan dan perbaikan hukum untuk mengisi kebutuhan baru dari masyarakat yang berkembang. ${ }^{5}$

Lembaga Bantuan Hukum (LBH) Cirebon sebagai bagaian dari Lembaga bantuan hukum memiliki peran strategis di Cirebon dan Indonesia pada umumnya yaitu dalam pembangunan hukum sebagaimana tujuan didirikanya yaitu melindungi masyarakat tidak mampu, mendorong kesadaran hukum masyarakat serta berperan kritis terhadap kebijakan hukum negara yang tidak berpihak dan merugikan khusunya di wilayah pengadilan negeri Cirebon melalui keterlibatannya

${ }^{5}$ Binziad Kadafi,dkk, Advokat Indonesia mencari legitimasi study tentang tanggung jawab profesi hukum di Indonesia, Pusat Studi Hukum dan Kebijakan Indonesia, Jakarta,2002,hlm.163 
dalam penanganan perkara pidana terhadap terdakwa yang membutuhkan jasan bantuan hukum. Keberadaan fungsi dan peran Lembaga Bantuan Hukum Cirebon sebagai lembaga bantuan hukum menjadi ruang yang dibutuhkan masyarakat yang sedang mengalami masalah hukum pidana agar proses penegakan hukum sesuai dengan aturan dan tidak menyimpang, Sebagai sebuah organisasi tentunya kebutuhan akan SDM dan anggaran menjadi penentu dalam setiap penanganan perkara oleh karenanya proses rekrutmen SDM dan sumber sumber pendanaan yang ada di Lembaga Bantuan Hukum Cirebon sangat dibutuhkan dalam rangka eksistensi organisasi bantuan hukum, belum lagi menyangkut legalitas LBH Cirebon yang harus tunduk pada Undang-undang Bantuan Hukum No.16 Tahun 2011 yang mewajibkan agar terakreditasi untuk bisa mengakses dana bantuan hukum yang disediakan negara melalui APBN.

Berdasarkan latar belakang permasalahan di atas, peneliti merasa tertarik untuk membahas masalah ini dengan judul : Eksistensi Lembaga Bantuan Hukum (LBH) Cirebon dalam Pendapingan Perkara Pidana di Pengadilan Negeri Cirebon.

\section{B. Perumusan masalah}

Adapun yang menjadi pokok permasalahan yang akan menjadi fokus perhatian utama yang akan dibahas dalam penelitian ini dapat di uraikan dalam pertanyaan diantaranya sebagai berikut:

1. Bagaimana pengaturan lembaga Bantuan Hukum Berdasarkan Undang-Undang Bantuan Hukum No.16 Tahun 2011 Tentang Bantuan Hukum?

2. Bagaimana Eksistensi Lembaga Bantuan Hukum (LBH) Cirebon dalam 
penanganan perkara Pidana di Pengadilan Negeri Cirebon?

\section{Metode Penelitian}

Metode penelitian yang digunakan oleh penyusun dalam pembahasan penelitian ini adalah metode evaluatif analisis, yaitu suatu metode mengumpulkan dan menyajikan data yang diperoleh untuk menganalisis keadaan yang sebenarnya dan selanjutnya dilakukan analisa rasional berdasarkan acuan yuridis melalui penelitian kepustakaan dan penelitian lapangan. Metode penelitian hukum, menurut Soerjono Soekanto adalah "suatu kegiatan ilmiah, yang di dasarkan pada metode, sistematika dan pemikiran tertentu, yang bertujuan mempelajari satu atau beberapa gejala hukum tertentu, dengan menganalisanya. ${ }^{6}$

\section{Pembahasan}

Pemberian bantuan hukum sebagaimana fungsi dan peran lembaga bantuan hukum dalam rangka pendampingan hukum bagi masyarakat yang mengalami masalah hukum baik litigasi maupun non litigasi tentu tidak terlepas dari penjabaran pengertian pengertian tentang bantuan hukum itu sendiri dan tentang jasa advokat sebagai sentral dalam pemberian advokasi di pengadilan dalam perkara pidana.Berikut adalah pengertian tentang bantuan hukum, yaitu :

1. Undang-Undang No.18 Tahun 2003 Tentang advokat pasal 1 angka 9 "Bantuan Hukum adalah Jasa hukum yang diberikan oleh advokat secara Cuma-Cuma kepada klien yang tidak mampu ".

\footnotetext{
${ }^{6}$ Soerjono Soekanto, Pengantar Penelitian Hukum.cet.2007, ( Jakarta : UI Press, 1984), hlm.5

${ }^{7}$ UU RI No.18 Tahun 2003 pasal 1 angka 9 Tentang Advokat
} 
2. Undang-undang No.16 Tahun 2011 Tentang Bantuan Hukum pasal 1 angka 1 "Bantuan Hukum adalah jasa hukum yang diberikan oleh pemberi bantuan hukum secara Cuma-Cuma kepada penerima bantuan hukum". 8

3. Pemberian bantuan hukum terdiri dari legal aid dan legal assistance, istilah legal aid diartikan sebagai pemberian bantuan hukum Cuma-Cuma kepada masyarakat yang tidak mampu sedangkan legal asistance yaitu bantuan hukum secara Cuma-Cuma dan pendampingan yang mengunakan jasa honorarium sebagai jasa hukumnya. ${ }^{9}$

Berdasarkan pengertian diatas maka secara prinsipil bantuan hukum merupakan proses pemberian jasa hukum yang dilakukan oleh advokat,pengacara atau pemberi bantuan hukum terhadap masyarakat yang tidak mampu atau miskin secara Cuma-Cuma agar mereka dapat memperjuangkan hak-hak hukumnya selama menjalani proses pemeriksaan di pengadilan. Istilah lain dari bantuan hukum yang banyak beredar di masyarakat adalah advokasi yang dalam pengertianya adalah kegiatan-kegiatan yang menyangkut aktivitas mempengaruhi penguasa atau lembaga lembaga menyangkut masalah masalah yang dialami oleh rakyat kecil atau rakyat tidak mampu dan miskin, terutama terhadap mereka yang dikucilkan atau dipingrikan dari proses politik, ekonomi dan sosial. ${ }^{10}$

Secara prinsip berdasarkan penjelasan diatas antara advokasi dan bantuan hukum memilki kesamaan yang pada intinya adalah pemberian

\footnotetext{
${ }^{8}$ UU RI No.16 Tahun 2011 pasal 1 angka 1Tentang Bantuan Hukum

${ }^{9}$ Yahya Harahap,Pembahasan dan Penerapan KUHAP : Penyidikan dan Penuntutan, Sinar Grafika, Jakarta,2009,hlm.334.

${ }^{10}$ Valerie Miller dan Jane Copey,Pedoman Advokasi :Kerangka kerja Untuk Perencanaan, Tindakan dan Refleksi, Yayasan Obor Indonesia, Jakarta, 2005,hlm.12.
} 
jasa hukum terhadap masyarakat tidak mampu baik secara hukum maupun politi, ekonomi dan sosial, tujuan pemberian bantuan hukum adalah terciptanya keadilan yang merata dan adanya perlindungan hukum dan hak asasi bagi warganegara khusunya yang tidak mampu, persamaan prinsip tersebut dapat diuraikan sebagai berikut :

1. Bantuan hukum itu merupakan suatu hak, ini berarti bahwa subyek hukum berhak mendapatkan bantuan hukum bila ia memerlukanya.

2. Bantuan hukum itu merupakan suatu pekerjaan yang profesional yang dilakukan oleh orang tertentu berdasarkan syarat-syarat tertentu.

3. Bantuan hukum itu merupakan pemberian jasa kepada orang yang memerlukanya yg dilakukan oleh orang tertentu.

4. Bantuan hukum itu diberikan untuk semua aspek kehidupan. ${ }^{11}$

Pada dasarnya bantuan hukum dapat dilakukan oleh advokat berdasarkan UU Advokat dan dapat dilakukan oleh Pemberi Bantuan Hukum berdasarkan UU Bantuan Hukum, tentu kedepan harus ada sinkronisasi definisi dan pengertian karena dalam peraktek dilapangan hanya advokat saja yang dapat melakukan pendampingan perkara di Pengadilan, tentu hal demikian menjadi masalah yang dapat berakibat pada proses penegakan hukum dimasayarakat. Penanganan Perkara Pidana merupakan bagian dari hukum pidana formil yaitu berdasarkan pada aturan aturan yang ada dalam Kitab Undang-undang Hukum Acara Pidana (KUHAP) No.8 Tahun 1981, maka proses pemberian bantuan hukum yang dilakukan oleh pemberi bantuan hukum atau advokat tentunya mengikuti aturan yang ada dalam KUHAP tersebut

\footnotetext{
${ }^{11}$ Abdurahman, Aspek-aspek Bantuan Hukum di Indonesia, Cendana Press,Jakarta,1983,hlm.22
} 
berdasarkan hukum acaranya menyangkut tekhins maupun non tekhnis. Disilain ada kewajiban hukum dalam KUHAP tentang kewajiban pendampingan oleh advokat atau pemberi bantuan hukum sebagaimana pada pasal 56 ayat (1) yaitu "Dalam hal tersangka atau terdakwa telah disangka atau didakwa melakukan tindak pidana yang diancam dengan pidana mati atau ancaman pidana lima belas tahun atau lebih dan atau bagi mereka yang tidak mampu yang diancam pidana lima tahun atau lebih yang tidak mempunyai penasehat hukum sendiri, pejabat yang bersangkutan pada semua tingkat pemeriksaan dalam proses peradilan wajib menunjuk penasehat hukum bagi mereka". ${ }^{12}$

Hal tersebut diatas berarti negera telah memberikan perlindungan kepada tersangka, terdakwa atau bagi mereka karena tidak mampu dapat diberikan jasa hukum Cuma Cuma yang akan ditunjuk oleh pejabat pada semua tingkatan pemeriksaan khusunya dipengadilan dalam perkara piudana. Adapun baiaya yang akan dikeluarkan oleh penasehat hukum tersebut dalam sejrahnya pertama melalui Mahkamah Agung RI dan dalam perkembanganya sejak adanya Undang-undang RI No.16 Tahun 2011 Tentang Bantuan hukum menjadi kewenangan Kementrian Hukum dan HAM RI meskipun memang proses pembiayaanya hanya diberikan kepada organisasi bantuan hukum yang sudah terakreditasi berdasarkan Undang-undang tersebut.

Pemberian bantuan hukum oleh Lembaga Bantuan Hukum sebagaimana diatur dalam Undang-undang Bantuan Hukum No.16 Tahun 2011 dalam pasal 1 memberikan pengertian pengertian sebagai berikut :

12 UURI No.8 Tahun 1981 Tentang Kitab Undang-Undang Hukum Acara Pidana pasal 56 ayat 1 
1. Bantuan hukum adalah jasa hukum yang diberikan oleh pemberi bantuan hukum secara Cuma Cuma kepada penerima bantuan hukum.

2. Penerima bantuan hukum adalah orang atau kelompok orang miskin.

3. Pemberi bantuan hukum adalah lembaga bantuan hukum atau organisasi kemasyarakatan yang memberi layanan bantuan hukum berdasarkan undang-undang bantuan hukum.

4. Menteri adalah menteri yang menyelenggarakan urusan pemerintah di bidang hukum dan hak asasi manusia.

5. Standar bantuan hukum adalah pedoman pelaksanaan pemberi bantuan hukum yang ditetapkan oleh menteri.

Dalam pasal lain yaitu menyangkut ruang lingkup pemberian bantuan hukum terdapat pada pasal 4 ayat (1), (2) dan (3) yaitu:

1. Bantuan hukum diberikan kepada penerima bantuan hukum yang menghadapi masalah hukum.

2. Bantuan hukum sebagaimana dimaksud meliputi masalah keperdataan, TUN , pidana dan perkara non litigasi.

3. Bantuan hukum sebagaimana dimaksud meliputi menjalankan kuasa, mendampingi, mewakili, membela, atau melakukan tindakan hukum lain untuk kepentingan hukum penerima bantuan hukum.

Sedangkan dalam definisi lain ketentuan mengenai kewenangan negara yang dalam hal ini dilaksanakan oleh menteri hukum dan HAM RI terdapat dalam pasal 6 ayat 1 dan 2 yang berbunyi :

1. Bantuan hukum diselenggarakan untuk membantu pnyelesaian permasalahan hukum yang dihadapi penerima bantuan hukum. 
2. Pemberi bantuan hukum kepada penerima bantuan hukum diselenggarakan oleh menteri dan dilaksanakan oleh pemeberi bantuan hukum berdasarkan undang-undang ini.

3. Pendampingan perkara pidana yang dilakukan oleh lembaga bantuan hukum ataupun advokat sangatlah penting fungsi dan peranya selain memang ditur dalam Kitab Undang-undang Hukum Acara Pidana juga diatur oleh Undang-undang Advokat dan Undang-undang Bantuan Hukum tentu tujuannya adalah adanya perlindungan hukum terhadap tersangka ataupun terdakwa yang diancam hukuman mati atau masyarakat yang tidak mampu untuk mendapatkan jasa advokat yang untuk memnyewanya butuh biaya yang sangat mahal, maka dengan adanya pendampingan dari lembaga bantuan hukum termasuk Lembaga Bantuan Hukum (LBH) Cirebon menjadi penting fungsi dan peranya dalam menegakan hukum pidana sebagaimna fungsinya yaitu mengatur dan menyelenggarakan kehidupan masyarakat agar dapat tercipta dan terpeliharanaya ketertiban umum. ${ }^{13}$

4. Proses pemeberian bantuan hukum oleh lembaga bantuan hukum dipengadilan dalam perkara pidana harus sesuai dengan syarat syarat yang telah ditetapkan oleh UU bantuan hukum dan aturan lainya karena hal tersebut sangart penting dalam eksistensinya memberikan pendampingan yang maksimal terhadap tersangka dan terdakwa di pengadilan agar apa yang menjadi hak hak mereka dapat terpenuhi sesuai dengan asas-asas dalam hukum pidana dan hukum acara pidana.

13 Adami Chazawi, Pelajaran Hukum Pidana,Raja Grafindo Persada,Jakarta,2005,hlm.15 
1. Eksisitensi Lembaga Bantuan Hukum Cirebon dalam Penanaganan Perkara Pidana.

Bahwa Lbh Cirebon merupakan Organisasi bantuan hukum yang beralamat di JI.Karimun Jawa No.44 Perumahan Griya Nusantara kelurahan Sunyaragi kecamatan Harjamukti Kota Cirebon, Legalitas LBH Cirebon adalah sebuah yayasan bantuan hukum yang tercatat dikementrian dan terakreditas oleh kementrian hukum dan Ham RI dengan nilai akreditasi $C$ yang berarti memiliiki kewenangan legal untuk dapat menerima dana bantuan hukum melalui APBN (Anggaran Pendapatan Belanja Negara), APBD (Anggaran Pendapatan Belanja Daerah) maupun donator lainya yang consent terhadap bantuan hukum diwilayah hukum Pengadilan Negeri Cirebon. Lbh Cirebon berdiri berdasarkan legalitas sebagai berikut :

1. Undang Undang No. 16 Tahun 2011 Tentang Bantuan Hukum.

2. PP No.42 Tahun 2013 tentang Bantuan Hukum.

3. Permenkumham No. 3 Tahun 2013 Jo Permenkumham No.10 tahun 2015 Tentang Verifikasi Organisasi dan Peraturan Pelaksana Peraturan Bantuan Hukum.

Bantuan hukum seharusnya memperhatikan faktor-faktor yang menyebabkan ketidakadilan bagi masyarakat miskin dan faktor-faktor penghambat ketika masyarakat miskin berusaha mengakses bantuan hukum tersebut. Pengalaman masyarakat miskin ketika mengakses bantuan hukum itulah yang kemudian dituangkan dalam berbagai peraturan perundang-undangan mengenai bantuan hukum sehingga bantuan hukum tidak semata- 
mata diartikan sebagai jasa dari pengacara kepada masyarakat miskin melainkan merefleksikan realitas yang dihadapi. Konstitusi menjamin hak setiap warga neraga mendapat perlakuan yang sama di muka hukum, termasuk hak untuk mengakses keadilan melalui pemberian bantuan hukum. Orang kaya dan mempunyai kekuasaan, dengan mudah mengakses dan mendapatkan "keadilan", melalui tangan-tangan advokat yang disewanya. Tidak demikian halnya kelompok masyarakat miskin, mereka tidak mampunyai kemampuan untuk memahami hukum dan tidak mampu untuk membayar advokat, hal demikian menyebabkan tidak ada perlakuan yang sama dimuka hukum untuk mengakses keadilan. Problem dasar yang muncul adalah tidak adanya perluasaan akses yang sama bagi setiap warganegara untuk mendapatkan perlakuan yang sama dimuka hukum, meskipun doktrinnya keadilan harus dapat diakses oleh semua warga negara tanpa terkecuali.

Sebagai LBH yang terakreditasi kewajiban LBH Cirebon adalah melakukan penanganan perkara Litigasi dan Non litigasi untuk merembus dan menangani perkara sebanyak 20 perkara litigasi dan 3 perkara non litigasi, adapun perkara litigasi dan non litigasi sebagai berikut :

1. Litigasi : adalah perkara yang masuk dalam ruang pengadilan yaitu :

a. perkara pidana,

b. perdata dan

c. Tata Usaha Negara. 
2. Non Litigasi : adalah perkara di luar persidangan yaitu;

a. Penyuluhan hukum

b. Konsultasi hukum

c. Mediasi

d. Konsiliasi

e. Penelitian hukum

f. Pemberdayaan masyarakat

g. Penanganan perkara diluar pengadilan

h. Drafting hokum

Berdasarkan penjelasan tersebut diatas maka penulis hanya fokus pada kewenangan LBH Cirebon dalam penanganan perkara pidana saja dalam penelitian ini, oleh karenanya penejelasan nya nanti tidak banyak menguraikan tentang eksistensi dalam penanganan perkara di luar perkara pidana, dalam melaksanakan kewenanganya LBH Cirebon dalam menangani perkara pidana yaitu berdasarkan UU Bantuan hukum hanya terfokus pada rakyat tidak mampu khusunya dan tersangka atau terdakwa yang diancam dengan hukuman 5 tahun keatas dan yang bersangkutan tidak dapat membayar jasa advokat atau lawyer. Dari penelitian yang dilakukan melalui observasi lapangan didapatkan data sebagai berikut yaitu : Penanganan perkara pidana telah dilakukan dari mualai tahun 2014 dan 2015 dengan jumalah pada tahun 2014 sebanyak 23 kasus dengan total pembayaran APBN sebesar Rp.115.000.000,- (Seratus Lima Belas Juta Rupiah) dan pada tahun 2015 sebanyak 20 kasus dengan pembayaran APBN sebesar Rp.100.000.000,- (Seratus Juta 
Rupiah). Berdasarkan total jumlah penanganan dari tahun 2014 sampai dengan tahun 2015 yaitu 43 perkara pidana yang rata perkara tersebut di putus di Pengadilan negeri Cirebon. Adapun total pembayaran yang diterima oleh LBH Cirebon dari tahun 2014 ampai dengan tahun 2015 adalah sebesar Rp.200.000.000,- (Dua Ratus Juta Rupiah) dan dana tersebut seluruhnya dari APBN.

2. Hambatan dan Kendala dalam menajalankan penanganan Perkara Pidana.

Dalam melaksanakan penanganan perkara di pengadilan negeri Cirebon terkadang terdapat kendala kendala terutama menyangkut administrasi yang diperlukan dalam proses penyelesaian perkara juga dalan proses pencairan dana bantuan hukum, selain itu juga kendala Sumber Dana Manusia serta Sarana pra sarana menjadi bagian tak terpisahkan yang merupakan bagian dari kendala yang ada di LBH Cirebon, dari uraian diatas peneliti dapat membagi kendala yang terdapat pada LBH Cirebon dalam pennaganan perkara Pidana di Pengadilan Sebagai Berikut, yaitu :

1. Administrasi ; kendala ini berhubungan dengan wilayah administrasi lembaga seperti disiplin adinistrasi, surat menyurat, dokumen dokumen yang berhubungan dengan efektifitas jalanya lembaga dalam pelaksanaan program penangan perkara pidana itu merupakan kendalam administrasi dalam hal penanganan perkara, selanjutnya adminsistrasi yang berhubungan dengan pencairan dana bantuan hukum, yaitu :

a. Poto Copy KTP (kartu Tanda Penduduk)

b. KK ( Kartu Keluarga) 

c. SKTM (Surat Keterangan Tidak Mampu)
d. Surat Permohonan Bantuan Hukum
e. Surat Dakwaan
f. Surat Kuasa
g. Surat Tuntutan
h. Surat Pembelaan (Pledoi)
i. Putusan Pengadilan
j. Kwitansi kwitansi

Data diatas harus dipenuhi oleh LBH Cirebon dalam pencairan dana Bantuan Hukum, dan terkadang tidak jarang dalam pencairan kurang salah satu dokumen yang berimbas tidak dapat pencairan dana bantuan hukum.

2. SDM (Sumber Daya Manusia); dalam konteks ini peneliti berhasil mendapatkan data bahwa advokat dan Pengacara di Indonesia yang bias bersidang hanya yang meiliki sumpah pengadilan tinggi hal tersebut termaktub dalam Undang Undang RI No. 18 Tahun 2003 Tentang Advokat. Berdasarkan hal tersebut anggota LBH Cirebon yang notabene adalah advokat yang belum memiliki Berita Acara Sumpah Pengadilan Tinggi yaitu berjumlah 7 Orang sedangkan sisanya 3 sudah mempunyai BAS (Berita Acara Sumpah Pengadilan Tinggi), hal demikian juga berpengaruh terhadap akses luas penanganan perkara Pidana di Pengadilan Negeri Cirebon, karena pengadilan hanya mau menerima advokat atau lawyer yang meiliki BAS PT. 
3. Sarana dan Prasarana; Kendala ini menyangkut kebutuhan kebutuhan fisik dan non fisik yang berimbas pada lemahnya semangat melaksanakan program penanganan perkara di pengadilan, seperti tidak meiliki kantor yang strategis, tidak memiliki computer, telepon dan lain-lain.

Maka berdasarkan kendala tersebut peneliti menyimpulakan hal hal diatasseyogyanya harus di jadikan masalah dan harus diselesaikan dalam rangka perbaikan lembaga khususnya dalam penanganan perkara pidana di Pengadilan Negeri Cirebon.

\section{E. Penutup}

\section{Kesimpulan}

Dari hasil penelitian yang dilakukan oleh peneliti maka dapat disimpulkan sebagai berikut :

a. Bahwa proses penanganan perkara pidana oleh LBH Cirebon di Pengadilan Negeri Cirebon belum berjalan maksimal karena lebih banyak penanganan perkara yang diancam dengan hukuman 5 tahun penjara dan perkara narkoba sedangkan esensi dari UU bantuan hukum adalah tidak hanya di pengadilan tapi dimulai dari tingkat penyidikan di Kepolisian dan pra Penuntutan di Kejaksaan.

b. Bahwa SDM pada LBH Cirebon belum maksimal hal ini dikarenakan hanya ada dua advokat yang memiliki berita acara sumpah Pengadilan Tinggi sedangkan yang lainya hanya memiliki kartu advokat saja dan hal tersebut berimbas tidak bisanya beracara berdasarkan UU Advokat No.18 Tahun 2003. 


\section{Saran}

Bahwa untuk meningkatkan eksistensi LBH Cirebon kearah lebih baik dalam pendampingakan perkara bantuan hukum orang miskin disarankan agar tidak menunggu penetapan dari pengadilan apalgi terhadap perkara narkoba, akan lebih baik penanganan perkara pidana di mulai pendampinganya dari kepolisian dan kejaksaan selanjutnya sampai pengadilan sampai akhirnya melakukan upaya hukum lanjutan apabila diperlukan, Selanjutnya untuk peningkatan SDM disarankan LBH Cirebon melakukan rekrutmen advokat yang sudah memiliki Berita Acara Sumpah Pengadilan Tinggi (BASPT) agar dapat memaksimalkan proses penaganan perkara pidana di pengadilan negeri cirebon

\section{DAFTAR PUSTAKA}

Abdurahman, Aspek-aspek Bantuan Hukum di Indonesia, Cendana Press,Jakarta,1983

Soerjono Soekanto, Pengantar Penelitian Hukum.cet.2007, UI Press,Jakarta, 1984.

C.S.T. Kansil, Pengantar I/mu Hukum dan Tata Hukum Indonesia, Balai Pustaka, Jakarta, 1986.

Soerjono Soekanto, Ringkasan metode Penelitian Hukum Empiris, IndHill, Jakarta, 1990.

Ronni Hanitijo Soemitro, Metodologi Penelitian Hukum dan Jurimetri, Ghalia Indonesia, Jakarta, 1990 
Binziad Kadafi,dkk, Advokat Indonesia mencari legitimasi study tentang tanggung jawab profesi hukum di Indonesia, Pusat Studi Hukum dan Kebijakan Indonesia, Jakarta,2002

Valerie Miller dan Jane Copey,Pedoman Advokasi :Kerangka kerja Untuk Perencanaan, Tindakan dan Refleksi, Yayasan Obor Indonesia, Jakarta, 2005

Chazawi Adami, Pelajaran hukum pidana 1, Raja Grafindo Persada, Jakarta,2005

Sudiknon Mertokusumo, Mengenal Hukum (Suatu Pengantar), Liberty, Yogyakarta, 2007.

Yahya Harahap,Pembahasan dan Penerapan KUHAP : Penyidikan dan Penuntutan, Sinar Grafika, Jakarta,2009.

P.A.F. Lamintang, Dasar-dasar Hukum Pidana, Citra Aditya Bakti, Bandung,2011.

\section{PERATURAN PERUNDANG-UNDANGAN}

Undang-Undang Dasar 1945

Kitab Undang-Undang Hukum Pidana

Kitab Undang -undang Hukum Acara Pidana

Undang-Undang Nomor 18 Tahun 2003 Tentang Advokat

Undang-undang Nomor 16 Tahun 2011 Tentang Bantuan Hukum 